\title{
A Method for Extracting Intact RNA from Fruits Rich in Polysaccharides using Ripe Mango Mesocarp
}

\section{R. López-Gómez and M.A. Gómez-Lim \\ Department of Genetic Engineering Centro de Investigacion y de Estudios Avanzados-Irapuato, Apartado Postal 629, Irapuato GTO, México}

Additional index words. Mangifera indica, RNA extraction, mango, in vitro translation, fruits, northern blots

\begin{abstract}
A rapid and simple procedure is described for efficiently extracting intact RNA from mango (Mangifera indica L. cv. Manila) mesocarp, a tissue rich in polysaccharides. The RNA can be used for in vitro translation, northern blots, and cDNA synthesis. This method is applicable to other fleshy fruits rich in polysaccharides.
\end{abstract}

Plant development frequently involves changes in gene expression that are triggered by environmental signals and endogenous factors, such as plant growth regulators. Molecular analysis of these processes usually necessitates the isolation of purified RNA in intact form. This RNA can be used to make complementary DNA, analyze the RNA using a "northern" transfer technique, or it can be used for in vitro translation experiments. To be useful for molecular studies, RNA isolated from plant material should meet at least three criteria: 1) it should be intact enough to give accurate and reproducible migration patterns following gel electrophoresis; 2) the RNA should give high molecular weight products on in vitro translation; and 3) the yield of RNA should be sufficient so that a reasonable amount of tissue can be used.

Various protocols have been described for the isolation of RNA from plant tissues. Conventional methods involve the use of de-

Received for publication 8 Apr. 1991. Accepted for publication 2 Dec. 1991. We thank L. Herrera Estrella for his continuous support throughout this work. We also thank M. Gidekel for help with computer work. The support of the International Foundation for Science, grant E/1881-1 to M.A.G.L. is gratefully acknowledged. tergents such as sodium dodecyl sulfate (SDS) or cetyltrimethyl ammonium bromide (Taylor and Powell, 1982), $\mathrm{LiCl}$ precipitations (Thompson et al., 1983), hot and cold phenol extractions (Galau et al., 1981; Morgens et al., 1987), guanidinium compounds together with density gradient centrifugation in $\mathrm{CsCl}$ cushions (Chirgwin et al., 1979), proteinase K (Mozer, 1980), and combinations of some of the above (Logemann et al., 1987).

We are currently studying mango fruit ripening at the molecular level and, therefore, used several of these methods for RNA extraction in mango fruit, but without success. We encountered three main difficulties when evaluating these methods: 1) the RNA was degraded; 2) very low yields were obtained, or 3 ) the RNA could not be translated. We, therefore, developed a method for the isolation of intact, translatable RNA from ripe mango mesocarp based on the use of tris.borate and precipitation with $20 \%$ ethanol (Su and Gibor, 1988).

Plant material. Mango fruits were harvested 15 weeks after anthesis from an 8year-old tree at the Instituto Nacional de Investigaciones Forestales, Agrícolas, y Pecuarias research station, Veracruz, México. The fruits were immediately transported to the laboratory and allowed to ripen at $25 \mathrm{C}$ and $65 \%$ relative humidity for 8 days. Once the fruits were ripe, as judged from texture and color, they were sliced, frozen in liquid nitrogen, and stored at $-80 \mathrm{C}$ until needed. Some fruits were sliced and frozen on arrival at the laboratory, i.e., the unripe fruit.

RNA extraction procedure. Frozen mesocarp tissue was homogenized in a polytron at full speed in lysis buffer (2\% SDS, $1 \%$ mercaptoethanol, $50 \mathrm{~mm}$ EDTA, and $150 \mathrm{~mm}$ tris base with $\mathrm{pH}$ adjusted to 7.5 with $1 \mathrm{M}$ boric acid; 2 to $3 \mathrm{ml} \cdot \mathrm{g}^{-1}$ fresh tissue) at room temperature. The homogenate was quickly vortexed with 0.25 volume of absolute ethanol and 0.11 volume of $5 \mathrm{~m}$ potassium acetate. Vortexing was continued for $1 \mathrm{~min}$, followed by chloroform isoamyl alcohol (49:1) extraction and centrifugation $(20,000 \times g$ for $10 \mathrm{~min})$. The recovered aqueous phase was extracted once with phenol-chloroform (1:1) and once with chloroform isoamyl alcohol (49:1). The aqueous phase was carefully removed, and the RNA was precipitated with $\mathrm{LiCl}$ (3 $\mathrm{M}$ final Concentration) at $-20 \mathrm{C}$ overnight. RNA was collected by centrifu-

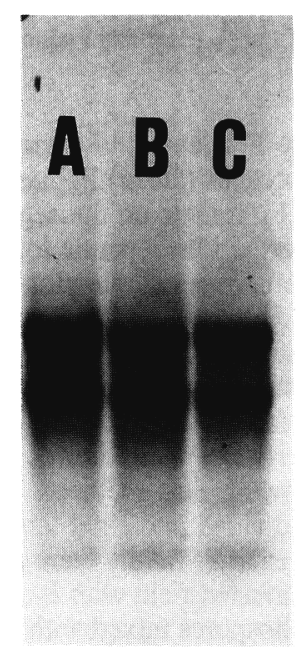

Fig. 1. Agarose gel electrophoresis of RNA. Total RNA $(10 \mu \mathrm{g})$ was fractionated by electrophoresis in a $1.5 \%$ gel prepared with TPE (see text). RNA was visualized by staining with ethidium bromide. Lane A, RNA from ripe fruit mesocarp; lane B, RNA from unripe fruit mesocarp; lane C, RNA of the peel of ripe fruit. 


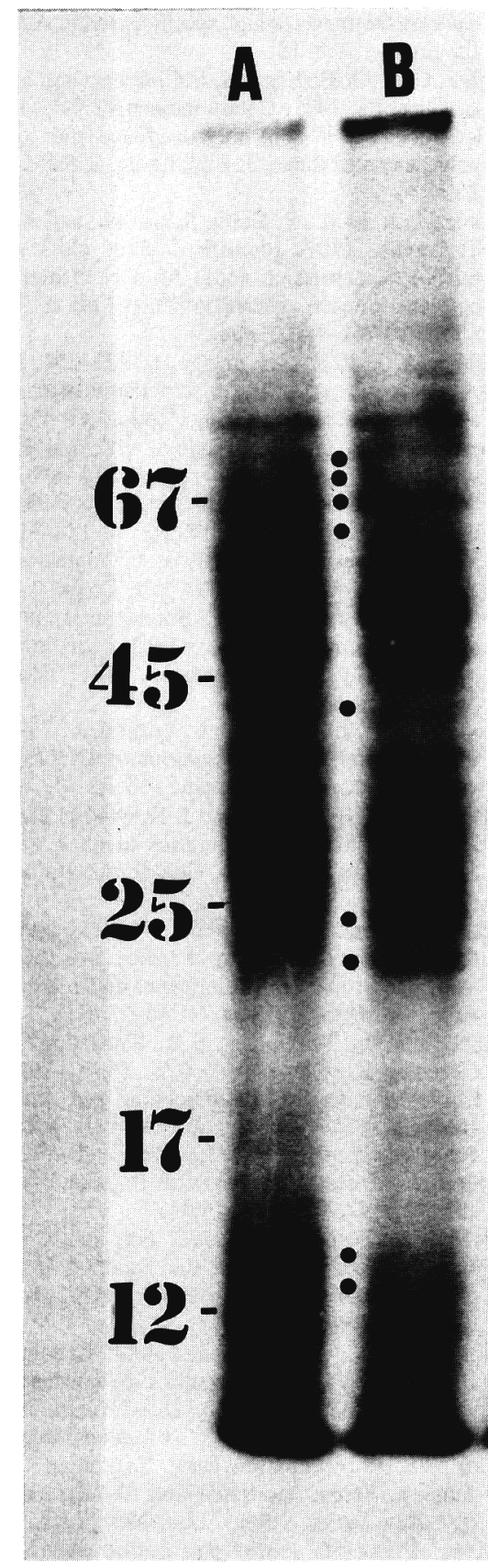

Fig. 12. Autoradiography of in vitro-translated mango proteins. Mango total RNA was translated in a wheat germ system. The protein products were electrophoresed in a $12 \%$ polyacrylamide gel. The gel was impregnated with En $n^{3}$ Hance [according to the manufacturer's (DuPont, Boston) instructions], dried, and exposed to XAR-5 film for $24 \mathrm{~h}$. Lane A, RNA from unripe fruit. Lane B, RNA from ripe fruit. The numbers indicate molecular weight markers in kiloDaltons. The dots indicate translation products that are only present in RNA from either ripe or unripe fruit.

gation $(20,000 \times g$ for $90 \mathrm{~min}$ at $4 \mathrm{C})$ and washed twice with $3 \mathrm{~m} \mathrm{LiCl}$. The RNA was then resuspended in sterile water, potassium acetate was added $(0.3 \mathrm{M}$ final concentration), and the RNA precipitated with two volumes of absolute ethanol. After incubation in ethanol overnight at $-20 \mathrm{C}$, the RNA

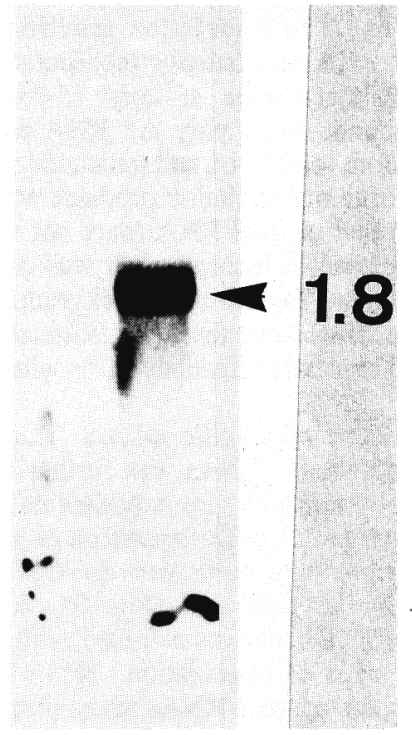

Fig. 3. Northern blot hybridization of a tomato ripening-specific clone against total RNA from ripe mango fruit. RNA $(20 \mu \mathrm{g})$ was separated on a $1.5 \%$ agarose-denaturing formaldehyde gel before transfer to a nitrocellulose filter and hybridization with the ${ }^{32} \mathrm{P}$-labeled tomato ripening-specific clone (pTOM 6). The number indicates the approximate size (in $\mathrm{Kb}$ ) of the message based on the resolution of RNA markers on the same gel.

was pelleted by centrifugation $(20,000 \times g$ for $10 \mathrm{~min}$ ), washed twice with $75 \%$ ethanol, and resuspended in sterile water. The RNA was quantitated spectrophotometrically, resuspended at a final concentration of 3 $\mathrm{mg} \cdot \mathrm{ml}^{-1}$, and stored at $-80 \mathrm{C}$. This method consistently gave good quality RNA.

In vitro translation system. Wheat germ extract was prepared as described by GomezLim et al. (1987) and used for in vitro translation of total RNA. The reactions were optimized for $\mathrm{K}^{+}$and $\mathrm{Mg}^{+2}$ and used under saturating RNA conditions. Incubations were done for $90 \mathrm{~min}$ at $25 \mathrm{C}$. Newly synthesized peptides were labeled by the incorporation of ${ }^{35}(\mathrm{~S})$-labeled methionine (New England Nuclear) from the $34 \mu \mathrm{Ci}(1 \mu \mathrm{Ci}=37 \mathrm{GBq})$ present in each translation reaction. The incorporated radioactivity was determined according to Mans and Novelli (1961). Generally, from 1 to $2 \times 10^{6} \mathrm{cpm}$ of trichloroacetic acid precipitable counts were obtained. For analysis by SDS-PAGE on $12 \%$ slab gels, 200,000 cpm were loaded per lane (Laemmli, 1970). The gels were stained (Coomassie blue R-250) to determine the migration of molecular weight markers and then exposed for $48 \mathrm{~h}$ to X-ray film (XAR5, Eastman Kodak, Rochester, N.Y.) at $-80 \mathrm{C}$.

Agarose gel electrophoresis. About $10 \mathrm{~kg}$ of total RNA was resolved on a $1.4 \%$ agarose gel at $70 \mathrm{~V}$ of constant voltage (Maniatis et al., 1982). The gel contained ethidium bromide $\left(1 \mu \mathrm{g} \cdot \mathrm{ml}^{-1}\right)$ and was prepared in TPE (80 mM tris base adjusted to $\mathrm{pH} 8.0$ with concentrated phosphoric acid, $2 \mathrm{~mm}$ EDTA).

Northern hybridizations. Total RNA (20

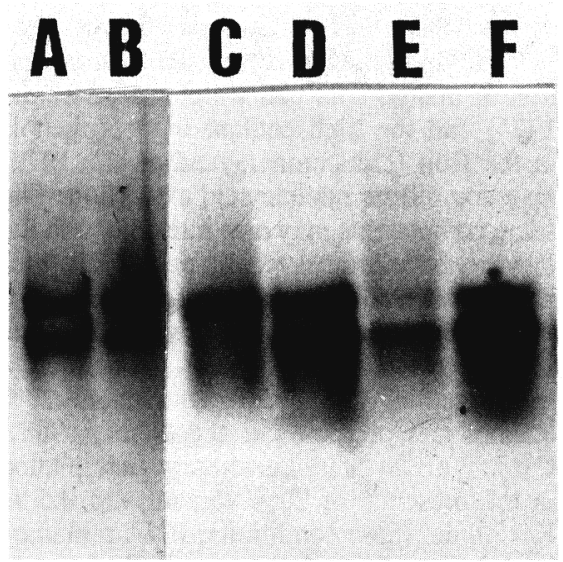

Fig. 4. Agarose gel electrophoresis of RNA extracted from various sources. Total RNA (from 10 to $20 \mu \mathrm{g}$ ) was fractionated by electrophoresis in a $1.5 \%$ gel prepared with TPE (see text). RNA was visualized by staining with ethidium bromide. Lane A, RNA from ripe avocado fruit mesocarp; lane B, RNA from ripe peach fruit mesocarp; Lane C, RNA from the flesh of ripe prickly pear fruit; lane D, RNA from ripe tomato pericarp; lane E, RNA from ripe strawberry achenes; lane F, RNA from Arabidopsis thaliana leaves.

$\mu \mathrm{g})$ was denatured with formaldehyde and resolved in a $1.5 \%$ agarose gel (Maniatis et al., 1982). The RNA was then transferred to nylon membranes by capillary action and fixed by UV light according to the manufacturers' instructions. The probe (pTOM 6, provided by D. Grierson, Nottingham Univ.) was labeled with ${ }^{32} \mathrm{P}$ by the random priming method (Feinberg and Vogelstein, 1983). The hybridization was performed at $60 \mathrm{C}$ without formamide in $5 \times \mathrm{SSPE}$ for $15 \mathrm{~h}$, and the filter was washed successively with several washes of $2 \times \operatorname{SSC}(20 \times$ SSC consists of 3 $\mathrm{M}$ sodium chloride and $0.3 \mathrm{M}$ sodium citrate adjusted to $\mathrm{pH} 7$ with concentrated $\mathrm{HCl}$ ), $1 \times \mathrm{SSC}$, and $0.1 \times \mathrm{SSC}(10 \mathrm{~min}$ each wash). The filter was then exposed to an X-ray film at $-70 \mathrm{C}$ with intensifying screens.

RNA extraction from mango fruit. Several methods for RNA isolation were used to isolate mango RNA. They all failed due to degradation of the RNA, low yield (less than 10 $\mu \mathrm{g}$ of total RNA per gram of fresh tissue), or because the RNA would not translate. One reason for the RNA degradation might have been the increase of RNases during mango fruit ripening. It has been shown that various enzyme activities increase during ripening, and RNases might be one of them (Mattoo et al., 1975). During mango ripening, insoluble starch is converted into soluble polysaccharides, and, as these polysaccharides display physicochemical properties similar to those of the RNA, they may contaminate the RNA during the extractions, probably affecting the yield (Logemann et al., 1987; McNeil et al., 1984). Such contamination might explain the low yield of RNA when using the methods mentioned above.

The main disadvantage of working with mango fruit is the high content of carbohydrate (Hulme, 1971; Lakshminarayana, 1980). 
This is a common problem with many tissues and prevents the use of conventional techniques. Additionally, the particular compositon of mango fruit cell walls (Saeed et al., 1975) and the high content of polyphenols in the fruit (Lakshminarayana et al., 1970) may complicate nucleic acid extraction. The same components may also interfere with the in vitro translation system, potentially preventing access to the RNA.

We, therefore, developed a method for the isolation of translatable RNA from mango fruit based on the use of tris.borate and $20 \%$ ethanol precipitation (Su and Gibor, 1988). Carbohydrates were selectively precipitated in the presence of $20 \%$ ethanol and $0.5 \mathrm{M}$ $\mathrm{K}^{+}$. Under these conditions, RNA remained in solution ( $\mathrm{Su}$ and Gibor, 1988). Lithium chloride precipitation also removed some carbohydrates. The presence of borate was necessary as it is known that borate forms $\mathrm{H}$-bonded complexes with polyphenols ( $\mathrm{Su}$ and Gibor, 1988).

This method consistently gave good yields of good quality RNA. The usual yield was 60 to $70 \mu \mathrm{g} \cdot \mathrm{g}^{-1}$ fresh tissue. The 260:280 ratio was always higher than 1.85 and the 230:260 ratio was 0.42. The corresponding figures for standard RNA (wheat germ RNA from Calbiochem, San Diego) were 2.0 and 0.43 , respectively.

Integrity of isolated RNA. Mango fruit RNA was analyzed by agarose gel electrophoresis. We obtained two discrete bands corresponding to the $25 \mathrm{~S}$ and $18 \mathrm{~S}$ ribosomal RNA (Fig. 1). About $98 \%$ to $99 \%$ of total RNA is ribosomal RNA; therefore, the integrity of an RNA sample can be determined by the integrity of ribosomal RNA. Distinct bands were present in the gels, suggesting that RNA degradation was not significant during the extractions. A faint background smear is also visible, probably corresponding to mRNA. A faint band, which may correspond to the $5 \mathrm{~S}$ RNA, is also visible at the bottom of the gel. We also isolated RNA from unripe fruit mesocarp and the peel, and the RNA looked intact in all cases (Fig. 1).

Efficiency of RNA translation in vitro. One important aspect concerning the quality of the RNA is its ability to be translated into protein in a cell-free system. Total RNA isolated from mango pericarp was translated in a wheat germ system (Fig. 2). The sizes of the translated polypeptides were up to 100 $\mathrm{kDa}$. We extracted RNA from ripe and unripe fruit and translated it in vitro. Several differences in the polypeptide populations were evident between the ripe and unripe fruit RNA, as indicated in the figure. This result suggests that new messengers are being expressed during ripening. These differences can be attributed to differences in the RNA populations. When translations were done without the addition of exogenous RNA, no products were visible on SDS gels after fluorography. The translation reactions with mango RNA consistently incorporated ${ }^{35} \mathrm{~S}$ labelled methionine at least 15 -fold over background. Also, poly $\mathrm{A}^{+}$RNA was prepared from total RNA and translated in vitro. The profile of translation products was identical to that of total RNA (data not shown), but the level of incorporation was considerably higher, 25-fold over background. This result confirms that the RNA isolated by this method translates efficiently in the wheat germ lysate.

Detection of specific $m R N A$. The intactness of specific RNAs was further demonstrated by northern blot experiments using a cDNA to a tomato (Lycopersicon esculentum Mill.) ripening-specific gene (pTOM 6, provided by D. Grierson) (Fig. 3). A sharp, well-defined band was obtained, with no apparent signs of degradation. This result indicates that specific RNAs in the preparation are intact and that there is some sequence homology between one ripening-specific gene of mango and tomato.

Extraction of RNA from other tissues. To evaluate the applicability of this method to other tissues, we extracted RNA from fruits of strawberry (Fragaria $\times$ ananassa Duch.), prickly pear [Opuntia tuna (L.) Mill.], tomato, avocado (Persea americana Mill.), and peach [Prunus persica (L.) Batsch], as well as from Arabidopsis thaliania (L.) Heynh leaves. Some of these tissues are rich sources of carbohydrates (strawberry, peach, and prickly pear fruits). In the analysis of these RNAs following agarose gel electrophoresis, the presence of the two ribosomal RNA bands is apparent in all cases (Fig. 4), suggesting intactness of the RNA. These RNAs have been translated in the wheat germ system and have given high incorporation rates similar to mango RNA (data not shown). The RNA yield for these tissues was similar to the yield for mango RNA (50 to $100 \mu \mathrm{g} \cdot \mathrm{g}^{-1}$ fresh tissue).

The RNA isolated by use of our method, as based on the method of Su and Gibor (1988), has been successfully used in our laboratory for various northern blot analyses as well as for cDNA cloning. A cDNA library has recently been prepared from ripe mango fruit, and several ripening genes have been isolated (unpublished data). Thus, the method described can be used for the isolation of intact, translatable RNA from various fruits and is specially suited for obtaining RNA from tissues rich in polysaccharides.

\section{Literature Cited}

Chirgwin, J.M., A.E. Przybyla, R.J. MacDonald, and W.J. Rutter. 1979. Isolation of biologically active ribonucleic acid from sources enriched in ribonucleases. Biochemistry 18:5294-5301.

Feinberg, A.P. and B. Vogelstein. 1983. A tech- nique for radiolabeling DNA restriction endonuclease fragments to high specitic activity. Anal. Biochem. 132:6-13.

Galau, G.A., A.B. Legocki, S.C. Greenway, and L. Dure, III. 1981. Cotton messenger RNA sequences exist in both polyadenylated and nonpolyadenylated forms. J. Biol. Chem. 256:25512560.

Gómez-Lim, M.A., P. Kelly, R. Sexton, and A.J. Trewavas. 1987. Identification of chitinase mRNA in abscission zones from bean during ethylene-induced abscission. Plant Cell \& Environ. 10:741-746.

Hulme, A.C. 1971. The mango, p. 233-254. In: A.C. Huhne (ed.). The biochemistry of fruits and their products. vol. 2. Academic, New York.

Laemmli, U.K. 1970. Cleavage of structural proteins during the assembly of the head of bacteriophage T4. Nature (London) 227:680-685.

Lakshminarayana, S. 1980. Mango, p. 184-257. In: S. Nagy and P.E. Shaw (eds.). Tropical and subtropical fruits. AVI, Westport, Conn.

Lakshminarayana, S., N.V. Subhadra, and H. Subramanyam. 1970. Some aspects of developmental physiology of mango fruit. J. Hort. Sci. 45:133-142.

Logemann, J., J. Schell, and L. Willmitzer. 1987. Improved method for the isolation of RNA from plant tissues. Anal. Biochem. 163:16-20.

Maniatis, T., E.F. Fritsch, and J. Sambrook. 1982. Molecular cloning: A laboratory manual. Cold Spring Harbor Laboratory, Cold Spring Harbor, N.Y.

Mans, R.J. and G.D. Novelli. 1961. Measurement of the incorporation of radioactive amino acids into protein by a filter paper disk method. Arch. Biochem. Biophys. 94:48-53.

Mattoo, A.K., T. Murata, E.B. Pantastico, K. Chachin, K. Ogata. and C.T. Phan. 1975. Chemical changes during ripening and senescence, p. 103-127. In: E.B. Pantastico (ed.). Post-harvest physiology, handling and utilization of tropical and subtropical fruits and vegetables. AVI, Westport, Conn.

McNeil, M., A.G. Darvill, S.C. Fry, and P. Albersheim. 1984. Structure and function of the primary cell walls of plants. Annu. Rev. Biochem. 53:625-663.

Morgens, P.H., J.B. Pyle, and A.M. Callahan. 1987. Searching for molecular mechanisms involved in fruit-ripening, p. 157-166. In: J.E. Fox and M. Jacobs (eds.). Molecular biology of plant growth control. Univ. California, Los Angeles, Symp. Molecular and Cellular Biology. New Series. vol 44. Liss, New York.

Mozer, T.J. 1980. Partial purification and characterization of the mRNA for alpha-amylase from barley aleurone layers. Plan Physiol. 65:834837.

Saeed, A.R., A.H. El Tinay, and A.H. Khattab. 1975. Characterization of pectic substances in mango. J. Food Sci. 40:205-206.

$\mathrm{Su}, \mathrm{X}$. and A. Gibor. 1988. A method for RNA isolation from marine macro-algae. Anal. Biochem. 174:650-657.

Taylor, B. and A. Powell. 1982. Isolation of plant DNA and RNA. Focus 4:4-6.

Thompson, W.F., M. Everett, N.O. Polans, R.A. Jorgensen, and J.D. Palmer. 1983. Phytochrome control of RNA levels in developing pea and mung-bean leaves. Planta 158:487-500. 